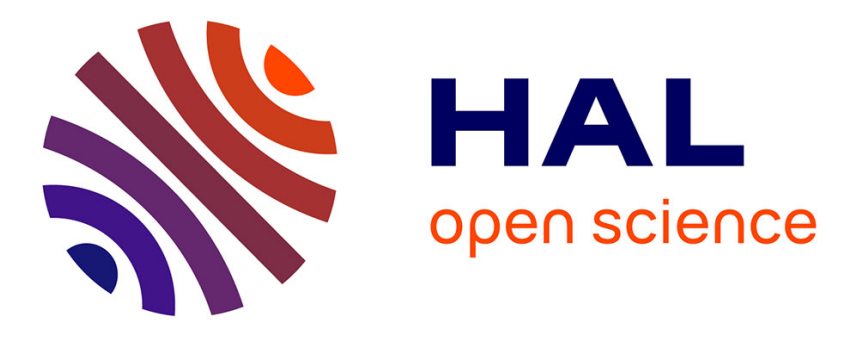

\title{
Modelling of the Electrical Conductivities in the Atmosphere of Ice Giants
}

Gregorio Molina-Cuberos, Olivier Witasse, Franck Montmessin, Jean-Jacques

Berthelier

\section{- To cite this version:}

Gregorio Molina-Cuberos, Olivier Witasse, Franck Montmessin, Jean-Jacques Berthelier. Modelling of the Electrical Conductivities in the Atmosphere of Ice Giants. Europlanet Science Congress 2020. Virtual Meeting, Copernicus Meetings, Sep 2020, Virtual Meeting, Germany. pp.EPSC2020-523. insu-02915716

\section{HAL Id: insu-02915716 https://hal-insu.archives-ouvertes.fr/insu-02915716}

Submitted on 15 Aug 2020

HAL is a multi-disciplinary open access archive for the deposit and dissemination of scientific research documents, whether they are published or not. The documents may come from teaching and research institutions in France or abroad, or from public or private research centers.
L'archive ouverte pluridisciplinaire HAL, est destinée au dépôt et à la diffusion de documents scientifiques de niveau recherche, publiés ou non, émanant des établissements d'enseignement et de recherche français ou étrangers, des laboratoires publics ou privés. 
EPSC Abstracts

Vol.14, EPSC2020-523, 2020, updated on 15 Aug 2020

Europlanet Science Congress 2020

(C) Author(s) 2020. This work is distributed under

the Creative Commons Attribution 4.0 License.

\section{Modelling of the Electrical Conductivities in the Atmosphere of Ice Giants}

Gregorio J. Molina-Cuberos ${ }^{1}$, Olivier Witasse ${ }^{2}$, Frank Montmessin ${ }^{3}$, and Jean-Jacques Berthelier ${ }^{4}$

${ }^{1}$ Dept. Electromagnetism and Electronic, University of Murcia, Murcia, Spain (gregomc@um.es)

${ }^{2}$ European Space Agency, ESA/ESTEC, Directorate of Science, Noordwijk, Netherlands (owitasse@cosmos.esa.int)

${ }^{3}$ Laboratoire Atmosphères, Milieux, Observations Spatiales, Guyancourt, France (franck.montmessin@latmos.ipsl.fr)

${ }^{4}$ Laboratoire Atmosphères, Milieux, Observations Spatiales, Guyancourt, France (jean-jacques.berthelier@latmos.ipsl.fr)

Many studies were carried out recently regarding the exploration of Ice Giants, in the context of the next NASA decadal survey in planetary sciences and astrobiology, of the next planning cycle in ESA's Science Programme, and of a possible NASA-ESA collaboration. A mission to an Ice Giant could include an atmospheric probe, to operate in the 1-10 bars pressure range. Its payload could comprise sensor(s) devoted to the measurement of electrical properties, plasma densities and conductivities.

In order to check the performances of such instruments, it is necessary to develop models of the electron and ion densities profiles, with and without aerosols, from which the electrical conductivities can be derived.

A model was developed based on studies performed at Mars and Titan [1-2], which computes the atmospheric positive and negative electrical conductivities between 0.1 and 15 bars in the atmosphere of Neptune and Uranus. In this altitude range, galactic cosmic rays ionize the atmospheric constituents, which react with atmospheric neutrals and aerosols, leading to the formation of ions heavier than the ones produced by cosmic rays. The densities of positive ions, electrons and charged aerosols are obtained by solving their corresponding continuity equations. It has been found that aerosol particles tend to be negatively charged due to the attachment of electrons, as a more efficient process than the attachment of positive ions. Therefore, the electrical conductivity due to negative charges is strongly reduced compared to the one expected when aerosols are not present. However, the electrical conductivity due to positive ions does not change so dramatically. The experimental determination of both components of the electrical conductivity can be useful to understand the properties of aerosols, plasma and electric currents in the atmospheres of Ice Giants.

Figure 1 and 2 shows some the first results of the number density and electrical conductivities in the atmospheres of Uranus and Neptune. They were calculated for a cosmic rays flux valid for a heliocentric potential of $100 \mathrm{MV}$, neglecting the planetary internal magnetic field, a mean ion mass of 100 amu and the aerosol particle distribution reported by Toledo et al. [3-4], which is extended down to the pressure range here considered. 


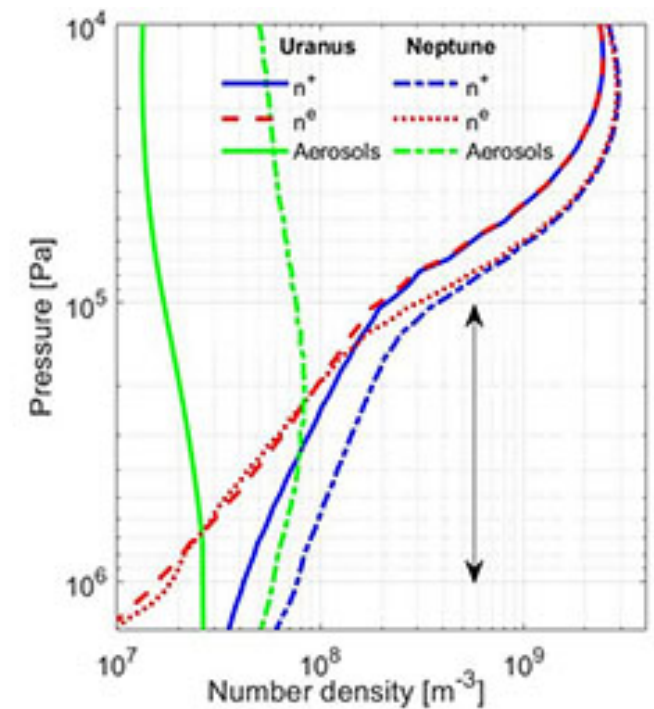

Fig 1. Resulting ion and electron number densities in the Uranus and Neptune atmosphere. The total number of charges (electrons) attached in aerosols is also plotted. The double arrow shows the altitude measurement range for a proposed atmospheric probe

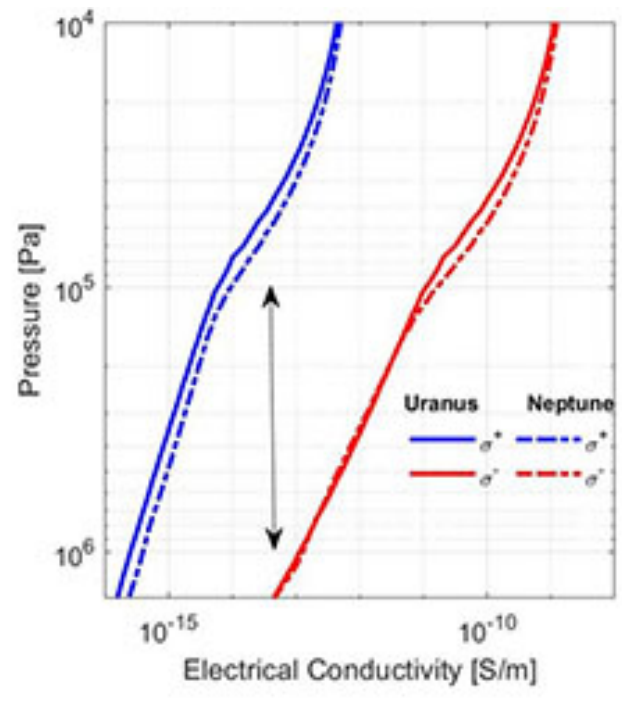

Fig 2. Electrical conductivities due to positive $\sigma^{*}$ and negative $\sigma$ charges in the atmosphere of Uranus and Neptune for the same conditions that Fig. 1. Due to their relatively high mass compared with that of electrons, aerosols do not contribute to $\sigma$.

\section{References}

[1] Cardnell, S., et al. (2016), A photochemical model of the dust-loaded ionosphere of Mars, ]. Geophys. Res. Planets, 121, doi:10.1002/2016JE005077.

[2] Molina-Cuberos, G.J., et al. (2018) Aerosols: The key to understanding Titan's lower ionosphere, Planet. Space Sci, 153, 157 - 162, doi: 10.1016/j.pss.2018.02.007.

[3] Toledo et al. (2019), Constraints on Uranus's haze structure, formation and transport, Icarus 0019-1035, doi: 10.1016/j.icarus.2019.05.018

[4] Toledo et al. (2020) Constraints on Neptune's haze structure and formation from VLT observations in the H-band, Icarus, doi: 10.1016/j.icarus.2020.113808 